\title{
IGF-IEc Expression Is Associated With Advanced Differentiated Thyroid Cancer
}

\author{
APOSTOLOS K. KARAGIANNIS ${ }^{1,2}$, ANASTASSIOS PHILIPPOU ${ }^{1}$, \\ SOFIA TSELENI-BALAFOUTA ${ }^{2}$, EVAGGELOS ZEVOLIS ${ }^{1}$, THEODORA NAKOUTI ${ }^{3}$, \\ MARIA TSOPANOMICHALOU-GKLOTSOU ${ }^{4}$, VASILIS PSARRAS ${ }^{5}$ and MICHAEL KOUTSILIERIS ${ }^{1}$
}

\author{
${ }^{1}$ Department of Physiology, Medical School, National and Kapodistrian University of Athens, Athens, Greece; \\ ${ }^{2}$ First Department of Pathology, Medical School, National and Kapodistrian University of Athens, Athens, Greece; \\ ${ }^{3}$ Fourth Department of Internal Medicine, Hippokration General Hospital, Medical School, \\ Aristotle University of Thessaloniki, Thessaloniki, Greece; \\ ${ }^{4}$ Department of Surgery, Yong Loo Lin School of Medicine, National University of Singapore, Singapore, Singapore; \\ ${ }^{5}$ Orofacial Pain Clinic, Dental School, National and Kapodistrian University of Athens, Athens, Greece
}

\begin{abstract}
Background/Aim: Recent knowledge implicates a differential expression of the insulin-like growth factor-I (IGF-I) mRNA splice variants (i.e., IGF-IEa, IGF-IEb and $I G F-I E c)$ in cancerous tissues, implying possible specific roles of the encoded IGF-I protein isoforms in cancer biology. In particular, there is growing evidence that the IGF-IEc isoform may play a distinct biological role in various types of cancers. The present study investigated whether IGF-IEc expression is associated with a particular type of thyroid cancer. Materials and Methods: Formalinfixed paraffin-embedded tissue specimens of different types of thyroid cancers from 92 patients were assessed for IGFIEc expression by immunohistochemistry. In addition, thyroid cancer biopsies of different TNM staging histological types were evaluated for mRNA expression of the IGF-IEc transcript by real-time polymerase chain reaction (PCR). Results: From the total number of 92 samples, 2 were anaplastic, 10 medullary, 4 hyperplasias of C-cells, 11 follicular, 5 hurtle cell carcinomas, 2 poorly differentiated, 5 nodular hyperplasias, 1 lymphoma and 52 were papillary thyroid cancers. The age of cancer diagnosis or tumor size did not significantly affect the IGF-IEc expression. Among all types of cancers, IGF-IEc was expressed in papillary differentiated thyroid cancer. Its expression/localization was mainly cytoplasmic and significantly associated with TNM
\end{abstract}

Correspondence to: Dr. Michael Koutsilieris, MD, Ph.D., Department of Physiology, Medical School, National \& Kapodistrian University of Athens, 75 Micras Asias, Goudi-Athens, 115 27, Greece. Tel: +30 2107462506, Fax: +30 2107462571, e-mail: mkoutsil@med.uoa.gr

Key Words: Thyroid cancer, insulin-like growth factor-I (IGF-I), IGF-IEc. staging and the presence of muscular and capsule cancerous invasion $(p<0.05)$. Similarly, a differential profile was revealed regarding the $m R N A$ expression of the IGF-IEc transcript, that exhibited a higher expression in aggressive compared to the non-aggressive papillary cancers. Conclusion: IGF-IEc isoform expression in thyroid cancer is positively associated with more advanced stages of papillary thyroid cancer.

Thyroid cancer accounts for the $1 \%$ of all human neoplasias and is the most common endocrine cancer. Over the last decades, its rate has developed rapidly because of the multiple, congregate environmental factors and the rapid advances in diagnostic radiology tools that detect small size cancers, that otherwise would remain undiagnosed. Basically, thyroid cancer is classified in 4 main categories; the differentiated cancer (papillary and follicular thyroid cancer), the poorly differentiated, the medullary cancer, which derives from parafollicular $\mathrm{C}$ cells of thyroid, and the anaplastic cancer, which has the poorest prognosis $(1,2)$.

Several common oncogenes, such as RAS, RET, BRAF and p53, have been involved in thyroid carcinogenesis (3). However, these are rarely used as prognostic factors in everyday clinical practice, since their frequency varies depending on the population while they mainly reflect the different genetic and environmental factors that induce carcinogenesis (1). On the other hand, insulin-like growth factor-I (IGF-I) regulates various aspects of cancer biology, such as cell proliferation, survival, differentiation and migration (4-7) and, thus, it has been implicated in the pathophysiology and progression of several human cancers (8-12).

IGF-I is secreted by the liver under the control of growth hormone $(\mathrm{GH})$, but is also produced by other organs such as skeletal muscle, kidney and brain (13-24). The Igf-l gene 
Table I. Sequence of specific sets of primers used in mRNA real-time PCR analysis.

\begin{tabular}{llc}
\hline Target mRNA & PCR Primer Sequence & Product Size (bp) \\
\hline IGF-IEc & 5'-CGAAGTCTCAGAGAAGGAAAGG-3' & 150 \\
GAPDH & 5'-ACAGGTAACTCGTGCAGAGC-3' & 293 \\
& 5'-TCAAGAACGAAAGTCGGAGG-3' & \\
\hline
\end{tabular}

Primers were designed to include sequences from different exons, to ensure the specific detection of only the transcript of interest and to avoid amplification of a similar-sized product from contaminating genomic DNA.

consists of 6 exons and can produce multiple heterogeneous transcripts via alternative splicing during its transcription. Specifically, parts of the exons 3 and 4 encode the mature IGF-I peptide, while alternative splicing of exons 5 and 6 results in three different IGF-I transcripts, namely the IGF-IEa, IGF-IEb, and IGF-IEc, encoding the corresponding IGF-I protein isoforms $(20,22)$.

Mature IGF-I peptide represents the common bioactive product of all IGF-I isoforms $(20,25)$ and multiple studies have shown that this peptide is involved in cell survival and apoptosis, as well as in the process of uncontrolled cell proliferation, which generally characterizes cancer development $(7,26,27)$. These IGF-I functions have been shown to affect various types of human cancer cells, such as prostate, breast and osteosarcoma cells $(5,28-32)$, while IGFI has also been shown to contribute to neovascularization (33), tumor aggressiveness and cancer cell migration (34).

Interestingly, there is a growing body of evidence pointing out for a distinct, IGF-I isoform-related expression pattern in the pathophysiology of various cancer models, in vitro and in vivo $(8,10,30,31,35-37)$. Although the biological significance of the IGF-I isoforms is, yet, not fully understood, their differential regulation in the pathophysiology of various cancers $(10,30,35)$ may indicate their discrete biological roles beyond mature IGF-I, potentially via the putative $\mathrm{Ea}, \mathrm{Eb}$ and Ec peptides $(8,14$, $16,30-32,38-40)$, that are produced by post-translational cleavage of the IGF-I isoforms (propeptides) $(20,38)$. In particular, the IGF-IEc isoform produces a bioactive Ec peptide, whose action has been documented to be mediated via an IGF-I receptor-independent mechanism (8, 14-16, 30, 39 ) and has been postulated to be oncogenic (41).

IGF-I expression has been previously reported in thyroid follicular cell lines in vitro (42), while in a recent study a positive correlation was revealed between serum IGF-I levels and the development of differentiated thyroid cancer (43). Nevertheless, to the authors' best knowledge there are no studies investigating the expression of the different IGF-I isoforms in thyroid cancer. Given the potentially distinct biological role, particularly of the IGF-IEc isoform and its posttranslational product Ec peptide in various cancers $(10$,
$30,41,44)$, the aim of the present study was to characterize the expression and localization of IGF-1Ec in thyroid cancer and investigate whether its expression is associated with a particular type, in terms of differentiation state and metastatic behavior of thyroid cancer.

\section{Materials and Methods}

Ethical approval. A retrospective selection of thyroid tissue diagnostic biopsy samples was performed from the archives of the Pathology Department of the "Laiko" University Hospital and this research approach was approved by the Ethics Committee of the hospital, while all experimental procedures conformed to the Declaration of Helsinki.

Patients. Formaldehyde-fixed and paraffin wax embedded thyroid tissue samples, derived from ninety-two patients who underwent total or near total thyroidectomy for histologically proving thyroid carcinoma within the last decade, were retrospectively selected from the archives of the Pathology Department of the "Laiko" University Hospital of Athens. The patients were between 13 and 76 years of age, while in four histological reports the age was not given. Based on the pathology reports, detailed information was recorded and analyzed regarding the tumor aggressiveness, stage, and any possible muscular, vascular or capsular invasion. A copy of the official pathology report provided by a certified pathologist was kept in file for all cases, while all tissue specimens were further reevaluated and confirmed by another pathologist.

Immunohistochemical analysis. Paraffin wax-embedded thyroid tissue samples were processed for paraffin sections and the Bondmax automated system (Leica Microsystems, New Castle, Newcastle Upon Tyne, UK) was used for the immunohistochemical (IHC) staining of the sections. The sections were then incubated with a specific anti-human IGF-IEc antibody (45) at a dilution of 1:1,000 in PBS, as previously described (14). Secondary biotinylated goat anti-rabbit IgG antibody (Dako Real EnVision, Glostrup, Denmark) was used and tissue sections were visualized under light microscopy. Prostate cancer biopsy sections were used as positive control (30), while control for the specificity of the reactions obtained in immunohistochemical analysis was performed by substituting the primary anti-IGF-IEc antibody with the antibody diluent (PBS) minus the primary antibody (negative control). Each section was then evaluated independently by two blinded trained pathologists, using intermediate-power light microscopy. One representative tumor section was evaluated per 
A

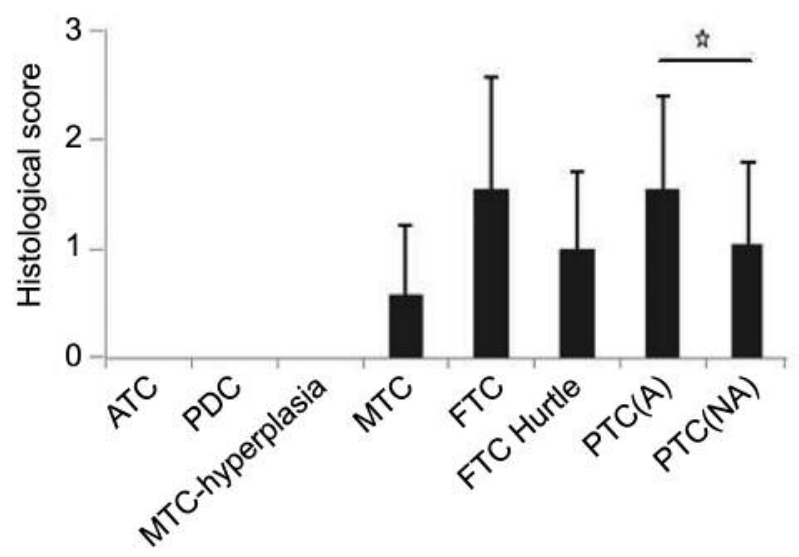

C

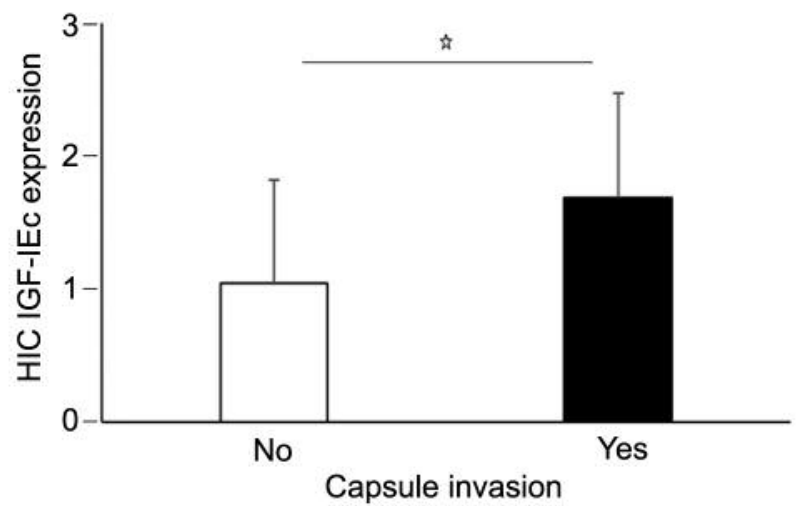

E

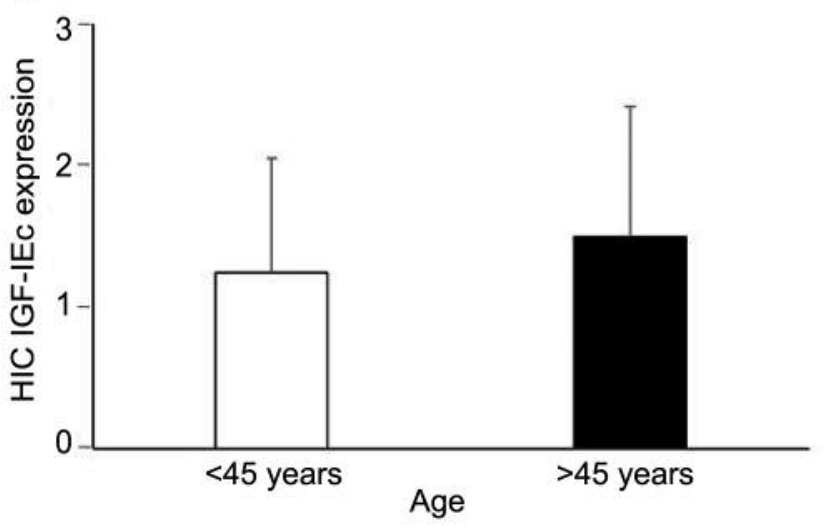

B



D

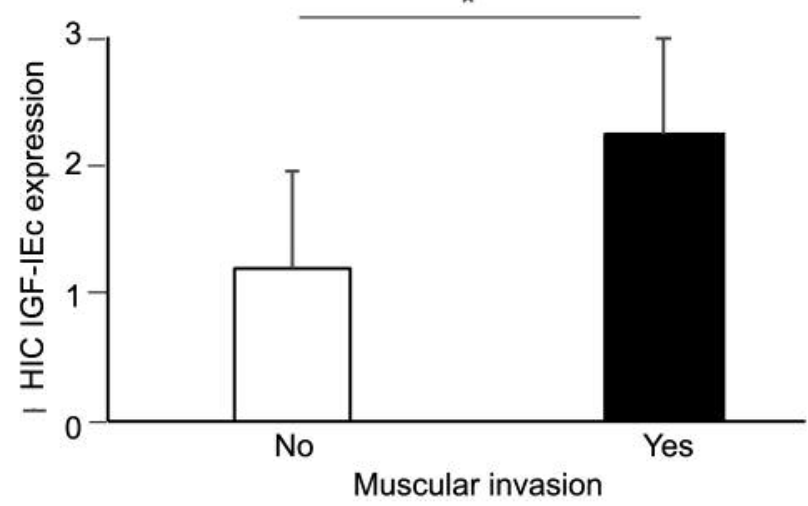

$\mathbf{F}$



Figure 1. A: Histological score of different thyroid cancers. Asterisk indicates the significantly higher expression of IGF-IEc in aggressive (A) papillary thyroid cancer (PTC) compared to non-aggressive (NA) PTC, according to the TNM staging. Panels depict the comparison of IGF-IEc IHC expression in terms of B: Recurrence risk stratification, C: Presence or absence of capsule invasion, D: Presence or absence of muscular invasion, E: Age, and F: Tumor size. Significantly different at *p<0.05. FTC: Follicular thyroid cancer; MTC: medullary thyroid cancer; MTCHyperplasia: hyperplasia of c-cells; PDC: poorly differentiated cancer; ATC: anaplastic thyroid cancer.

case. Localization of IGF-IEc was assessed and categorized as either grade 1 (weak intensity), grade 2 (moderate intensity) or grade 3 (strong intensity) according to both intensity and distribution of the staining.
RNA Extraction and Real-time Polymerase Chain Reaction (RT-PCR) analysis. Intact total RNA became possible to extract from six paraffin wax embedded thyroid tissue samples of different TNM staging (i.e., 3 aggressive and 3 non-aggressive papillary cancers) 
Table II. Relationship between IGF-IEc expression and pathological variables of 52 papillary thyroid cancer samples.

\begin{tabular}{lc}
\hline Variables & $\begin{array}{c}\text { Association with } \\
\text { IGF-IEc expression }\end{array}$ \\
\hline Age (13-76 years) & \\
30 subjects $<45$ yrs & \\
22 subjects $>45$ yrs & \\
TNM Stage & \\
Low: 23 & \\
Intermediate: 21 & \\
High: 8 & \\
Surgical margins & \\
Negative: 50 & $\mathrm{~ns}$ \\
Positive: 2 & \\
Capsule invasion & \\
Absent: 25 & $p<0.05$ \\
Present: 27 & \\
Vascular invasion & \\
Absent: 47 & \\
Present: 5 & $\mathrm{~ns}$ \\
Tumor size $(<0.5 \mathrm{~mm}-6.5 \mathrm{~cm})$ & \\
$<2$ cm: 31 & \\
$2-4$ cm: 17 & \\
$>4$ cm: 4 & \\
Lymph nodes & \\
Absent: 47 & \\
Present: 5 & \\
Muscular invasion & \\
Absent: 45 & \\
Present: 7 & \\
Foci & \\
Multifocal: 21 & \\
Unifocal: 31 & \\
\hline
\end{tabular}

ns: Not significant.

after homogenizing tissue specimens, and using TRIzol reagent according to the manufacturer's instructions (Invitrogen, Carlsbad, CA, USA). The extracted RNA was dissolved in diethylpyrocarbonate (DEPC)-treated water and the concentration and purity were determined spectrophotometrically (Genova, Jenway, Essex, UK) by absorption at 260 and $280 \mathrm{~nm}$. The quality and integrity of total RNA were assessed by visual inspection of the electrophoretic pattern of $18 \mathrm{~S}$ and $28 \mathrm{~S}$ ribosomal RNA in ethidium bromide-stained $1 \%$ agarose gels under ultraviolet (UV) light. The RNA samples were used for the determination of the mRNA expression profile of the IGF-IEc isoform by reverse transcription and semi-quantitative real time-PCR procedures.

Specifically, $1 \mu \mathrm{g}$ of total RNA from each sample was used for the production of single-stranded cDNA by means of reverse transcription (QuantiTect, Qiagen, Hilden, Germany) and the resultant complementary DNA (cDNA) was used in real-time PCR analyses. Real-time PCR was performed with the use of the BioRad 96-well iCycler thermal cycler (Bio-Rad iQ5 Real-Time PCR Detection System; Hercules, CA, USA) and Kapa Biosystems reagents (Kapa SYBR Fast qPCR Kit, Boston, MA, USA). The primer set sequences used for the specific detection of the IGF-IEc transcipt are presented in Table I. In particular, to prevent detection
A DNA Marker A A A NA NA NA \begin{tabular}{|lll}
\hline \\
\hline
\end{tabular}

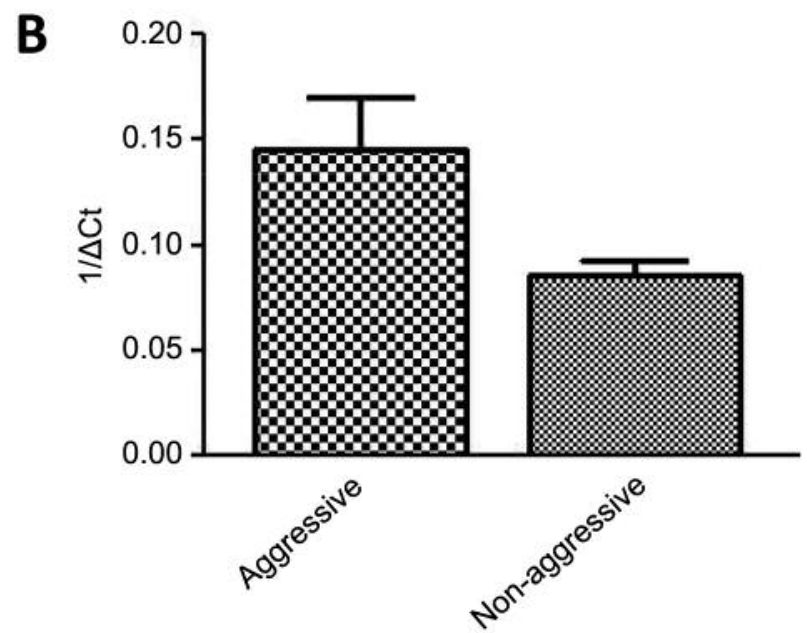

Figure 2. A: Representative PCR gel image demonstrates the expression of the IGF-IEc transcript in thyroid tissues derived from three aggressive $(A)$ and three non-aggressive (NA) cancers according to TNM staging. B: Semi-quantitative real-time RT-PCR analysis. Threshold cycle (Ct) values of the IGF-IEc transcript for each sample were normalized ( $\triangle C t s)$ to each corresponding reference gene $(G A P D H)$. Because greater Ct values correspond to smaller expression, levels of relative expression are represented as the reversed difference

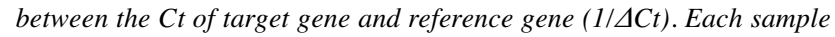
was analyzed in triplicate, and the resulting data were averaged (means $\pm S D$ ).

of genomic DNA and to detect and amplify only the specific, IGFIEc transcript, the primers were designed to lie within different exons of the $I g f-1$ gene. That target sequence has been previously identified by sequencing analysis, ensuring specificity of the primers (16). The real-time PCR parameters were the following: initial denaturation at $95^{\circ} \mathrm{C}$ for 5 minutes followed by 40 cycles of 15 seconds at $95^{\circ} \mathrm{C}, 30$ seconds at $62^{\circ} \mathrm{C}$ for annealing, and 30 seconds at $72^{\circ} \mathrm{C}$ for extension. All real-time PCR reactions were performed at $20 \mu \mathrm{l}$ final volume using $50 \mathrm{ng}$ cDNA as a template. IGF-IEc transcript levels were assessed by automatically calculating the threshold cycle $(\mathrm{Ct})$ as the number of cycles at which the measured fluorescence exceeds the threshold for detection. Glyceraldehyde 3-phosphate dehydrogenase (GAPDH) was used as housekeeping gene (internal standard) for the relative quantification $(\mathrm{dCt})$ of the specific, IGF-IEc transcript expression. Each sample was analyzed in triplicate, and the resulting data were averaged. A 



Figure 3. An example of the IGF-IEc expression/localization in thyroid tissues, as detected by immunohistochemical (IHC) analysis in paraffin sections stained with a specific polyclonal rabbit anti-human IGF-IEc antibody. Arrows indicate the expression/localization, which is mainly cytoplasmic, in papillary thyroid cancer ( $A, B$ and $C$ panels) as well as in minimally invasive follicular thyroid cancer (D panel). Magnification: A and $B \times 100, C$ and $D \times 400$.

melting curve (Tm) was also generated by the Bio-Rad iQ5 RealTime PCR Detection System software after the final cycle for each experimental sample, by means of continuous monitoring the Kapa SYBR fluorescence throughout the temperature ramp from $65^{\circ} \mathrm{C}$ to $95^{\circ} \mathrm{C}$. The specificity of the primers for the corresponding transcript was also confirmed by melting curve analysis of samples, where there was only 1 melting curve for each sample, and electrophoretic analysis of the real-time PCR products further verified the specificity of the target IGF-IEc transcript. Control for specificity included cDNA-free reactions.

Statistical analysis. Results are expressed as mean \pm standard error of the mean (SEM) unless otherwise indicated. Comparisons of IGF-IEc expression between two groups of values were performed using Student's $t$-test or Mann Whitney $U$-test, for parametric or non-parametric analysis, respectively. One-way analysis of variance (ANOVA) was used to assess differences between more than two groups. A $p$-value $<0.05$ was considered as statistically significant.
All statistical analyses were performed using StatView (SAS Institute, Carry, NC, USA).

\section{Results}

Of the total 92 samples, 2 were anaplastic, 10 medullary, 4 hyperplasia of C-Cell, 11 follicular, 5 hurtle Cell, 2 poorly differentiated, 5 nodular hyperplasia, 1 was lymphoma and 52 were papillary thyroid cancer. The characteristics of the tissue samples are presented in Table II. Specifically, according to their TNM stage, $23(44.2 \%)$ samples were of low, $21(40.4 \%)$ of intermediate and $8(15.4 \%)$ of high aggressiveness. From the total number of samples, capsule filtration was present in 27 (52\%) samples. Positive surgical margins were observed in 2 cases $(3.8 \%)$, muscular invasion 
in $7(13.5 \%)$, vascular invasion in $5(9.6 \%)$, while in other 5 cases $(9.6 \%)$ there were positive lymph nodes. The tumor size ranged from less than $0.5 \mathrm{~mm}$ to $6.5 \mathrm{~cm}$ and in 21 tissues $(40.4 \%)$ there were more than one foci.

IGF-IEc expression is associated with differentiated and medullary thyroid cancer. Among all types of cancer included in this study, HIC expression of IGF-IEc was observed only in medullary, follicular, hurtle cell and papillary carcinoma and not in anaplastic, hyperplasia of CCells or poorly differentiated cancer (Figure 1A).

IGF-IEc is highly expressed in differentiated papillary thyroid cancers. Among differentiated cancer types, IGF-IEc expression was high in papillary thyroid cancer while, interestingly, there was a significant difference between its expression in the more aggressive compared with the non-aggressive types, according to the TNM staging of the American Thyroid Association (ATA) $(p<0.05$; Figure 1A). Moreover, in terms of the recurrence risk stratification according to ATA guidelines (2015), there were statistical differences in IGF-IEc expression between all three groups, i.e., the low, intermediate or high-risk group $(p<0.05$; Figure 1B).

IGF-IEc mRNA expression is higher in aggressive compared to non-aggressive papillary cancers. To further investigate whether the expression of the IGF-IEc isoform is associated with the histological type of TNM staging, its mRNA expression was evaluated in thyroid tissue samples derived from three aggressive and three non-aggressive cancers. IGFIEc transcript exhibited an expression profile similar to that observed by IHC, i.e., a high expression in aggressive cancers (Figure 2A and B).

IGF-IEc expression in DTC is associated with the presence of capsular and muscular invasion. The IGF-IEc expression in differentiated thyroid cancer was significantly higher when muscular or capsular invasion was present than when was absent $(p<0.05$; Figure 1C and D).

Age and tumor size are not predicting factors of IGF-IEc expression. When samples were classified by age, as groups above or under $45 \mathrm{yrs}$ of age, no differences in IGF-IEc expression were found between the groups $(p>0.05$; Figure $1 \mathrm{E})$. Moreover, no significant differences were revealed when the tumors were classified based on their size, according to TNM staging, i.e., as below $2 \mathrm{~cm}$, between $2 \mathrm{~cm}$ and $4 \mathrm{~cm}$, or above $4 \mathrm{~cm}(p>0.05$; Figure $1 \mathrm{~F})$.

IGF-IEc exhibits cytoplasmic localization in thyroid cancer cells. Immunohistochemical analysis revealed the cytoplasmic expression of IGF-IEc, while positive staining was also present in the membrane of the thyroid cancer cells.
In particular, papillary thyroid cancer and minimally invasive follicular thyroid cancer appeared highly stained with the anti-IGF-IEc antibody, as seen in the representative images in Figure 3A-D (See also Figure 1A).

\section{Discussion}

The present study investigated the IHC expression of IGFIEc isoform in different types of thyroid cancer, revealing that IGF-IEc expression is positively associated with more aggressive thyroid cancer variables, as evidenced by the recurrence risk stratification index and the advanced cancer stages.

The investigation of the expression pattern of the IGF-I isoforms in various conditions and pathologies including cancer $(10,14-16,21,30,46,47)$ is of particular interest, as a differential regulation of the IGF-I isoforms in those pathologies may indicate a distinct biological role for the different IGF-I precursor polypeptides and/or their $\mathrm{Ea}, \mathrm{Eb}$ and Ec peptides. Although the role of particularly the E peptides of IGF-I remains as yet unclear (20), initial evidence has been provided recently that Ec peptide is differentially regulated during the process of muscle regeneration in humans (38) while the synthetic Ec peptide was documented to possess bioactivity $(8,14-16,39,48)$, and its over-expression in prostate cancer cells (PC-3) was found to increase their oncogenic potential in mice (41).

In particular, previous studies of our group have documented the mitogenic effect of an E domain-related product of the IGF-IEc isoform in human prostate cancer (PCa), breast cancer, endometrial and osteosarcoma cells, in vitro $(14,30-32,41)$, as well as a potential role of the IGFIEc isoform in the pathophysiology of bladder cancer (10) and neuroendocrine neoplasms (44), in vivo. Specifically, a differential expression of the IGF-IEc isoform has been detected in PCa and prostatic intraepithelial neoplasia, as well as in bladder cancer $(10,30)$ compared to the corresponding normal tissues. Herein we further demonstrated that its expression/localization in thyroid cancer cells was mainly cytoplasmic and significantly related to TNM staging and the presence of muscular and capsule cancerous invasion, exhibiting increased levels in the more aggressive compared with the non-aggressive types of thyroid cancer. The mRNA expression analysis of this specific, IGF-IEc transcript corroborated this association, i.e., the more aggressive the cancer type, the more intense the mRNA expression. These findings are in line with previous in vivo studies showing increased IGF-IEc expression in secondary compared to primary foci in neuroendocrine neoplasms (44), and that IGF-IEc expression was positively correlated with the prostate cancer stage and Gleason's score (28), implying a possible gradual increase of the IGF-IEc expression during the progress of the disease. 
To the best of our knowledge, the present study is the first demonstrating the expression pattern of IGF-IEc in different types of thyroid cancer revealing a positive association between the expression levels of this IGF-I isoform and the risk of disease recurrence. Another interesting finding of this study was that IGF-IEc expression was significantly associated with capsular and muscular invasion in DTC, while no association was revealed between IGF-IEc expression and vascular invasion or lymph node metastasis. Thus, it could be speculated that while IGF-IEc isoform is highly expressed in thyroid tumors with advanced histopathological stage, the mechanisms mediating the invasion into adjacent structures may not be IGF-IEcdependent. Whether IGF-IEc isoform expression could be evidence of the metastatic potential of the advanced thyroid tumors remains to be further investigated.

Moreover, no significant associations were revealed when the IGF-IEc expression was adjusted for age, tumor size or foci. Specifically, regarding tumor size, the total number of samples was divided into three groups according to the TNM staging and, although IGF-IEc expression was found to be higher in advanced cancer stage, this increased expression is possibly independent of the tumor size. Similarly, while the thyroid cancer is usually more aggressive in young patients however IGF-IEc expression was not found to be associated with the age of the patients.

Due to the limited number of follicular thyroid cancer (FTC) cases, any potential difference in the IGF-IEc expression between follicular adenoma (FA) and FTC was not analyzed in this study. The small number of cases could be also responsible for not detecting the expression of IGF-IEc in the undifferentiated cancer types, though the mechanisms underlying those cancers seem to be quite complex. More studies are needed to shed more light on the role of the IGFIEc isoform in the pathogenesis of other thyroid cancers.

Our study has certain limitations; firstly, its retrospective design includes the inevitable innate difficulty to isolate intact RNA from all the paraffin wax embedded tissue samples for the RT-PCR analyses; thus, the results regarding the mRNA expression should be interpreted with caution due to the limited number of thyroid tissue samples used. Similarly, we were not able to extract an adequate amount of protein from the paraffin-embedded samples to proceed with western blot analyses. Finally, some of the samples in the IHC intermediate risk population might have been biased, because they were selected and categorized as more aggressive/advanced thyroid cancers, mainly due to the lack of real distant metastatic cases. Thus, further studies including a larger number of samples in each cancer type population are needed to provide clearer evidence regarding the IGF-IEc expression profile in the various thyroid cancers.

In conclusion, the present study demonstrated that the expression of IGF-IEc isoform was positively associated with more a aggressive phenotype and advanced stage of differentiated thyroid tumors, as evidenced by several prognostic clinicopathological variables in our cohort of thyroid tumor samples. Thus, this study can be a resource to be used as a database providing the first evidence for the implication of IGF-IEc expression in thyroid cancer progression. The possible tumor type-specific regulation of the IGF-IEc isoform in the pathophysiology of cancer, as previously shown in various cancers, requires further investigation, in order to confirm whether this specific IGFI isoform could be used as a potential prognostic biomarker and/or a novel therapeutic target in cancer.

\section{Conflicts of Interest}

The Authors declare no conflict of interest.

\section{Authors' Contributions}

AK designed and performed the study, analyzed data and wrote the manuscript; AP designed the study, wrote and reviewed the manuscript; ST-B analyzed data and reviewed the manuscript; EZ contributed to the experimental processes and data analysis; TN analyzed data and reviewed the manuscript; MT-G contributed to the experimental processes; VP analyzed data and MK conceived and designed the experiments, analyzed data and reviewed the manuscript. All authors have read and approved the final manuscript.

\section{Acknowledgements}

The Authors recognize the invaluable contribution of the patients' biopsy samples utilization to this work.

\section{References}

1 Carling T and Udelsman R: Thyroid cancer. Annu Rev Med 65: 125-137, 2014. PMID: 24274180. DOI: 10.1146/annurev-med061512-105739

2 Shlomo Melmed S, Kenneth Polonsky KS, Larsen R and Kronenberg H: Williams textbook of endocrinology. Elsevier, Philadelphia, PA: 13nd Edition, 2016

3 Park JY, Yi JW, Park CH, Lim Y, Lee KH, Lee KE and Kim JH: Role of BRAF and RAS Mutations in Extrathyroidal Extension in Papillary Thyroid Cancer. Cancer Genomics Proteomics 13: 171-181, 2016. PMID: 26912807.

4 Reyes-Moreno C, Sourla A, Choki I, Doillon C and Koutsilieris M: Osteoblast-derived survival factors protect PC-3 human prostate cancer cells from adriamycin apoptosis. Urology 52: 341-347, 1998. PMID: 9697810. DOI: 10.1016/s0090-4295(98) 00182-4

5 Koutsilieris M, Mitsiades C and Sourla A: Insulin-like growth factor I and urokinase-type plasminogen activator bioregulation system as a survival mechanism of prostate cancer cells in osteoblastic metastases: Development of anti-survival factor therapy for hormone-refractory prostate cancer. Mol Med 6: 251267, 2000. PMID: 10949907. DOI: 10.1007/bf03401935 
6 Mitsiades CS, Mitsiades N and Koutsilieris M: The akt pathway: Molecular targets for anti-cancer drug development. Curr Cancer Drug Targets 4: 235-256, 2004. PMID: 15134532. DOI: $10.2174 / 1568009043333032$

7 Samani AA, Yakar S, LeRoith D and Brodt P: The role of the IGF system in cancer growth and metastasis: Overview and recent insights. Endocr Rev 28: 20-47, 2007. PMID: 16931767. DOI: 10.1210/er.2006-0001

8 Philippou A, Armakolas A and Koutsilieris M: Evidence for the possible biological significance of the igf-1 gene alternative splicing in prostate cancer. Front Endocrinol (Lausanne) 4: 31, 2013. PMID: 23519101. DOI: 10.3389/ fendo.2013.00031

9 Philippou A, Christopoulos PF and Koutsilieris DM: Clinical studies in humans targeting the various components of the igf system show lack of efficacy in the treatment of cancer. Mutat Res Rev Mutat Res 772: 105-122, 2016. PMID: 28528684. DOI: 10.1016/j.mrrev.2016.09.005

10 Mourmouras N, Philippou A, Christopoulos P, Kostoglou K, Grivaki C, Konstantinidis C, Serafetinides E, Delakas D and Koutsilieris M: Differential expression of igf-1 transcripts in bladder cancer. Anticancer Res 38: 3453-3459, 2018. PMID: 29848696. DOI: 10.21873 /anticanres.12614

11 Christopoulos PF, Corthay A and Koutsilieris M: Aiming for the insulin-like growth factor-1 system in breast cancer therapeutics. Cancer Treat Rev 63: 79-95, 2018. PMID: 29253837. DOI: 10.1016/j.ctrv.2017.11.010

12 Gkioka E, Msaouel P, Philippou A, Vlaghogiannis NI, Vogkou CT, Margiolis A and Koutsilieris M: Review: The role of insulinlike growth factor-1 signaling pathways in uterine leiomyoma. In Vivo 29: 637-649, 2015. PMID: 26546520.

13 Moschos MM, Armakolas A, Philippou A, Pissimissis N, Panteleakou Z, Nezos A, Kaparelou M and Koutsilieris M: Expression of the insulin-like growth factor 1 (igf-1) and type 1 igf receptor mRNAs in human hle-b3 lens epithelial cells. In Vivo 25: 179-184, 2011. PMID: 21471532.

14 Milingos DS, Philippou A, Armakolas A, Papageorgiou E, Sourla A, Protopapas A, Liapi A, Antsaklis A, Mastrominas M and Koutsilieris $\mathrm{M}$ : Insulin-like growth factor-1Ec (mgf) expression in eutopic and ectopic endometrium: Characterization of the MGF E-peptide actions in vitro. Mol Med 17: 21-28, 2011. PMID: 20844834. DOI: 10.2119/molmed.2010.00043

15 Stavropoulou A, Halapas A, Sourla A, Philippou A, Papageorgiou E, Papalois A and Koutsilieris M: Igf-1 expression in infarcted myocardium and MGF E peptide actions in rat cardiomyocytes in vitro. Mol Med 15: 127-135, 2009. PMID: 19295919. DOI: $10.2119 /$ molmed 2009.00012

16 Philippou A, Papageorgiou E, Bogdanis G, Halapas A, Sourla A, Maridaki M, Pissimissis N and Koutsilieris M: Expression of igf-1 isoforms after exercise-induced muscle damage in humans: Characterization of the MGF E peptide actions in vitro. In Vivo 23: 567-575, 2009. PMID: 19567392.

17 Philippou A and Barton ER: Optimizing igf-1 for skeletal muscle therapeutics. Growth Horm IGF Res 24: 157-163, 2014. PMID: 25002025. DOI: 10.1016/j.ghir.2014.06.003

18 Barton ER, Park S, James JK, Makarewich CA, Philippou A, Eletto D, Lei H, Brisson B, Ostrovsky O, Li Z and Argon Y: Deletion of muscle grp94 impairs both muscle and body growth by inhibiting local igf production. FASEB J 26: 3691-3702, 2012. PMID: 22649033. DOI: 10.1096/fj.11-203026
19 Durzynska J, Philippou A, Brisson BK, Nguyen-McCarty M and Barton ER: The pro-forms of insulin-like growth factor 1 (igf1) are predominant in skeletal muscle and alter igf-1 receptor activation. Endocrinology 154: 1215-1224, 2013. PMID: 23407451. DOI: 10.1210/en.2012-1992

20 Philippou A, Maridaki M, Pneumaticos S and Koutsilieris M: The complexity of the igf1 gene splicing, post-translational modification and bioactivity. Mol Med 20: 202-214, 2014. PMID: 24637928. DOI: 10.2119/molmed.2014.00011

21 Thomas CG, Psarros C, Gekas A, Vandoros GP, Philippou A and Koutsilieris M: Alternative splicing of igf1 gene as a potential factor in the pathogenesis of Peyronie's disease. In Vivo 30: 251256, 2016. PMID: 27107083.

22 Philippou A, Maridaki M, Halapas A and Koutsilieris M: The role of the insulin-like growth factor 1 (igf-1) in skeletal muscle physiology. In Vivo 21: 45-54, 2007. PMID: 17354613.

23 Bikle DD, Tahimic C, Chang W, Wang Y, Philippou A and Barton ER: Role of igf-i signaling in muscle bone interactions. Bone 80: 79-88, 2015. PMID: 26453498. DOI: 10.1016/j.bone. 2015.04.036

24 Tzanis G, Philippou A, Karatzanos E, Dimopoulos S, Kaldara E, Nana E, Pitsolis T, Rontogianni D, Koutsilieris M and Nanas S: Effects of high-intensity interval exercise training on skeletal myopathy of chronic heart failure. J Card Fail 23: 36-46, 2016. PMID: 27327970. DOI: 10.1016/j.cardfail.2016.06.007

25 Philippou A, Halapas A, Maridaki M and Koutsilieris M: Type I insulin-like growth factor receptor signaling in skeletal muscle regeneration and hypertrophy. J Musculoskelet Neuronal Interact 7: 208-218, 2007. PMID: 17947802.

26 Nagel JM, Geiger BM, Karagiannis AK, Gras-Miralles B, Horst D, Najarian RM, Ziogas DC, Chen X and Kokkotou E: Reduced intestinal tumorigenesis in apcmin mice lacking melaninconcentrating hormone. PLoS One 7: e41914, 2012. PMID: 22848656. DOI: 10.1371/journal.pone.0041914

27 Hakam A, Yeatman TJ, Lu L, Mora L, Marcet G, Nicosia SV, Karl RC and Coppola D: Expression of insulin-like growth factor-1 receptor in human colorectal cancer. Hum Pathol 30: 1128-1133, 1999. PMID: 10534157. DOI: 10.1016/s00468177(99)90027-8

28 Savvani A, Petraki C, Msaouel P, Diamanti E, Xoxakos I and Koutsilieris M: Igf-iec expression is associated with advanced clinical and pathological stage of prostate cancer. Anticancer Res 33: 2441-2445, 2013. PMID: 23749893.

29 Koutsilieris $\mathrm{M}$ and Polychronakos C: Proteinolytic activity against igf-binding proteins involved in the paracrine interactions between prostate adenocarcinoma cells and osteoblasts. Anticancer Res 12: 905-910, 1992. PMID: 1377896.

30 Armakolas A, Philippou A, Panteleakou Z, Nezos A, Sourla A, Petraki C and Koutsilieris M: Preferential expression of IGF-1Ec (mgf) transcript in cancerous tissues of human prostate: Evidence for a novel and autonomous growth factor activity of mgf e peptide in human prostate cancer cells. Prostate 70: 12331242, 2010. PMID: 20564425. DOI: 10.1002/pros.21158

31 Philippou A, Armakolas A, Panteleakou Z, Pissimissis N, Nezos A, Theos A, Kaparelou M, Armakolas N, Pneumaticos SG and Koutsilieris M: IGF-IEc expression in mg-63 human osteoblastlike osteosarcoma cells. Anticancer Res 31: 4259-4265, 2011. PMID: 22199289.

32 Christopoulos PF, Papageorgiou E, Petraki C and Koutsilieris M: The COOH-terminus of the IGF-1Ec isoform enhances the 
proliferation and migration of human mcf-7 breast cancer cells. Anticancer Res 37: 2899-2912, 2017. PMID: 28551627. DOI: 10.21873/anticanres.11643

33 Shigematsu S, Yamauchi K, Nakajima K, Iijima S, Aizawa T and Hashizume K: Igf-1 regulates migration and angiogenesis of human endothelial cells. Endocr J 46(Suppl): S59-62, 1999. PMID: 12054122. DOI: 10.1507/endocrj.46.suppl_s59

34 Brodt P, Fallavollita L, Khatib AM, Samani AA and Zhang D: Cooperative regulation of the invasive and metastatic phenotypes by different domains of the type i insulin-like growth factor receptor beta subunit. J Biol Chem 276: 33608-33615, 2001. PMID: 11445567. DOI: 10.1074/jbc.M102754200

35 Christopoulos PF, Philippou A and Koutsilieris M: Pattern of igf1 variants' expression in human cancer cell lines using a novel q-rt-pcr approach. Anticancer Res 35: 107-115, 2015. PMID: 25550540

36 Kasprzak A, Szaflarski W, Szmeja J, Andrzejewska M, Przybyszewska W, Kaczmarek E, Koczorowska M, Koscinski T, Zabel $\mathrm{M}$ and Drews M: Differential expression of igf-1 mRNA isoforms in colorectal carcinoma and normal colon tissue. Int $\mathrm{J}$ Oncol 42: 305-316, 2012. PMID: 23165777. DOI: 10.3892/ijo. 2012.1706

37 Christopoulos PF, Msaouel P and Koutsilieris M: The role of the insulin-like growth factor- 1 system in breast cancer. Mol Cancer 14: 43, 2015. PMID: 25743390. DOI: 10.1186/s12943-0150291-7

38 Vassilakos G, Philippou A and Koutsilieris M: Identification of the igf-1 processing product human Ec/rodent $\mathrm{Eb}$ peptide in various tissues: Evidence for its differential regulation after exercise-induced muscle damage in humans. Growth Horm IGF Res 32: 22-28, 2017. PMID: 27836414. DOI: 10.1016/ j.ghir.2016.11.001

39 Papageorgiou E, Philippou A, Armakolas A, Christopoulos PF, Dimakakos A and Koutsilieris M: The human ec peptide: The active core of a progression growth factor with species-specific mode of action. Hormones (Athens) 15: 423-434, 2016. PMID: 27838607. DOI: 10.14310/horm.2002.1699

40 Vassilakos G, Philippou A, Tsakiroglou P and Koutsilieris M: Biological activity of the e domain of the IGF-1Ec as addressed by synthetic peptides. Hormones (Athens) 13: 182-196, 2014. PMID: 24776619. DOI: 10.1007/bf03401333

41 Armakolas A, Kaparelou M, Dimakakos A, Papageorgiou E, Armakolas N, Antonopoulos A, Petraki C, Lekarakou M, Lelovas P, Stathaki M, Psarros C, Donta I, Galanos PS, Msaouel $\mathrm{P}$, Gorgoulis VG and Koutsilieris M: Oncogenic role of the ec peptide of the IGF-1Ec isoform in prostate cancer. Mol Med 21: 167-179, 2015. PMID: 25569803. DOI: 10.2119/molmed. 2014.00222
42 Tode B, Serio M, Rotella CM, Galli G, Franceschelli F, Tanini A and Toccafondi R: Insulin-like growth factor-1: Autocrine secretion by human thyroid follicular cells in primary culture. $\mathrm{J}$ Clin Endocrinol Metab 69: 639-647, 1989. PMID: 2547829. DOI: $10.1210 /$ jcem-69-3-639

43 Schmidt JA, Allen NE, Almquist M, Franceschi S, Rinaldi S, Tipper SJ, Tsilidis KK, Weiderpass E, Overvad K, Tjonneland A, Boutron-Ruault MC, Dossus L, Mesrine S, Kaaks R, Lukanova A, Boeing H, Lagiou P, Trichopoulos D, Trichopoulou A, Palli D, Krogh V, Panico S, Tumino R, Zanetti R, Bueno-deMesquita HB, Peeters PH, Lund E, Menendez V, Agudo A, Sanchez MJ, Chirlaque MD, Ardanaz E, Larranaga N, Hennings J, Sandstrom M, Khaw KT, Wareham N, Romieu I, Gunter MJ, Riboli E, Key TJ and Travis RC: Insulin-like growth factor-1 and risk of differentiated thyroid carcinoma in the european prospective investigation into cancer and nutrition. Cancer Epidemiol Biomarkers Prev 23: 976-985, 2014. PMID: 24646451. DOI: 10.1158/1055-9965.epi-13-1210-t

44 Alexandraki KI, Philippou A, Boutzios G, Theohari I, Koutsilieris M, Delladetsima IK and Kaltsas GA: IGF-1Ec expression is increased in secondary compared to primary foci in neuroendocrine neoplasms. Oncotarget 8: 79003-79011, 2017. PMID: 29108282. DOI: 10.18632/oncotarget.20743

45 Philippou A, Stavropoulou A, Sourla A, Pissimissis N, Halapas A, Maridaki M and Koutsilieris M: Characterization of a rabbit antihuman mechano growth factor (mgf) polyclonal antibody against the last 24 amino acids of the e domain. In Vivo 22: 2735, 2008. PMID: 18396778.

46 Armakolas N, Armakolas A, Antonopoulos A, Dimakakos A, Stathaki $M$ and Koutsilieris $M$ : The role of the IGF-1Ec in myoskeletal system and osteosarcoma pathophysiology. Crit Rev Oncol Hematol 108: 137-145, 2016. PMID: 27931832. DOI: 10.1016/j.critrevonc.2016.11.004

47 Armakolas N, Dimakakos A, Armakolas A, Antonopoulos A and Koutsilieris M: Possible role of the Ec peptide of IGF-1Ec in cartilage repair. Mol Med Rep 14: 3066-3072, 2016. PMID: 27571686. DOI: $10.3892 / \mathrm{mmr} .2016 .5627$

48 Armakolas A, Dimakakos A, Loukogiannaki C, Armakolas N, Antonopoulos A, Florou C, Tsioli P, Papageorgiou E, Alexandrou TP, Stathaki M, Spinos D, Pektasides D, Patsouris E and Koutsilieris M: Il-6 is associated to IGF-1Ec upregulation and Ec peptide secretion, from prostate tumors. Mol Med 24: 6, 2018. PMID: 30134795. DOI: 10.1186/s10020-018-0003-Z

Received April 22, 2019

Revised May 16, 2019

Accepted May 21, 2019 